\title{
Types and frequency of body postures and dental malocclusions
}

\section{Tipos y frecuencia de posturas corporales y maloclusiones dentales}

\author{
CAPETILLO-HERNÁNDEZ, Guadalupe Rosalía†*, TIBURCIO-MORTEO, Leticia, OCHOA- \\ MARTÍNEZ, Rosa Elena and TORRES-CAPETILLO, Evelyn Guadalupe
}

Universidad Veracruzana, Faculty of Dentistry, Veracruz, Mexico.

ID $1^{\text {st }}$ Author: Guadalupe Rosalía, Capetillo-Hernández / ORC ID: 0000-0002-2033-4660, Researcher ID Thomson: S7875-2018, CVU CONACYT ID: 386320

ID $1^{\text {st }}$ Co-author: Leticia, Tiburcio-Morteo / ORC ID: 0000-0003-1806-4355

ID $2^{\text {nd }}$ Co-author: Rosa Elena, Ochoa-Martínez / ORC ID: 0000-0002-0676-6387

ID $3^{\text {rd }}$ Co-author: Evelyn Guadalupe, Torres-Capetillo / ORC ID: 0000-0003-0576-0327, Researcher ID Thomson: T1680-2018, CVU CONACYT ID: 308188

DOI: $10.35429 /$ JEHW.2020.6.4.27.31

Received January 25, 2020; Accepted June 30, 2020

\begin{abstract}
The jaw is articulated with the skull through the temporomandibular joint. And the skull, in turn articulates with the spine (upper cervical). Important studies establish that up to $30-40 \%$ of back pain can be caused or aggravated by dental malocclusion. Objective. To establish the types and frequency of body postures and dental malocclusions in the patients of the School of Dentistry in the period August-December 2019. Methodology. Transversal, descriptive and observational study. The sample was made up of a total of 50 patients between the ages of 19 and 70 who attended the Admission Clinic of the School of Dentistry. To which were carried out: verification of molar class, verification of midline deviation, verification of posterior crossbite, external lateral palpation of the TMJ, extraoral photographs, analysis of photographs. Contribution. It was found that there is a high frequency of one type of body posture and Angle Class I malocclusions, in patients from the School of Dentistry. In relation to malocclusions, Angle Class I predominated, as well as flattened posture, in Class II military posture and in Class III both flattened and military posture.
\end{abstract}

\begin{abstract}
Resumen
La mandíbula se articula con el cráneo mediante la articulación temporomandibular. Y el cráneo, a su vez se articula con la columna vertebral (cervicales superiores). Estudios importantes establecen que hasta 30-40\% de los dolores de espalda pueden estar causados o agravados por una maloclusión dental. Objetivo. Establecer tipos y frecuencia que existen de posturas corporales y maloclusiones dentales en los pacientes de la Facultad de Odontología en periodo Agosto-diciembre 2019. Metodología. Estudio transversal, descriptivo y observacional. La muestra quedó conformada por un total de 50 pacientes con edades comprendidas entre 19 y 70 años que asistieron a la Clínica de Admisión de la Facultad de Odontología. A los cuales se realizó: verificación de clase molar, verificación de desviación de línea media, verificación de mordida cruzada posterior, palpación lateral externa de la ATM, fotografías extraorales, análisis de fotografías. Contribución. Se encontró que Existe una alta frecuencia de un tipo de Postura corporal y maloclusiones Clase I de Angle, en pacientes de la Facultad de Odontología. predominó el género femenino. En relación con las maloclusiones, la Clase I de Angle predominó, así como la postura aplanada, en Clase II la militar y en Clase III tanto la aplanada como la militar.
\end{abstract}

Maloclusiones, Postura corporal, Columna vertebral

Malocclusions, Body posture, Spine

Citation: CAPETILLO-HERNÁNDEZ, Guadalupe Rosalía, TIBURCIO-MORTEO, Leticia, OCHOA-MARTÍNEZ, Rosa Elena and TORRES-CAPETILLO, Evelyn Guadalupe. Types and frequency of body postures and dental malocclusions. Journal-Health Education and Welfare. 2020. 4-6:27-31.

\footnotetext{
* Correspondence of the Author (Email: gcapetillo@uv.mx)

$\dagger$ Researcher contributing as first author.
} 


\section{Introduction}

Malocclusion refers to the misalignment of the teeth or the way the upper and lower teeth fit together. Most people have some degree of malocclusion. With great frequency, malocclusion can be caused by different etiological factors, such as habits, heredity, nutrition, congenital and developmental defects of the individual and posture. Altered body posture creates or causes problems at the craniofacial level, which lead to functional, structural and aesthetic deterioration.

Alterations in body posture appear throughout the development of a subject's life and are due to the performance of activities of daily life such as; walking, running, sitting, bending over, carrying a backpack or a handbag and in a very special way sitting for a long time, either at work or at school, in a nonfunctional position, with uncomfortable and not very anatomical chairs.

The organism is a whole that works together, and the stomatognathic system is not isolated; Thus, the correct function of the stomatognathic system brings with it the harmonic development of the jaws and consequently the proper position of the teeth, because there is a relationship between the position of the head, jaw, hyoid bone, temporomandibular joints, infra hyoid region, airways and plantar footprint, in such a way that if the position of one of them is altered, it influences the position of the other, affecting the correct functions and promoting an adaptation of the stomatognathic system that later leads to dysfunction. (Inquilla et al., 2017).

Cranial position plays a fundamental role within the cranio-cervico-mandibular balance, indicating that its components have the potential capacity to influence each other. The location of the structures of this system is related to specific anatomical characteristics and functions such as lingual position, cervical and mandibular posture (Mariel, 2015).
The relationship between head posture and craniofacial morphological development was suggested by Schwartz and Bjork. The first evidence of such a causal relationship was observed in the studies carried out by Solow and Tallgrenen, and Siersback Nielsen, establishing that it is the posture that influences development and not the opposite. Body posture is an essential factor in the development of oral functions. Children with Class II malocclusion tend to keep their head upright and forward, and there is a significant correlation between malocclusion and cervical lordosis. In general, straightening of the cervical spine is orthopedically desirable and consistent with physiological straightening during growth observed in Angle class II patients and also indicated a relationship between body posture and malocclusion. Inquilla et al., (2017).

The human body remains standing thanks to the balance between the different kinesiological planes.

The alteration of one of these planes supposes a mismatch of the whole set. An occlusion with a large number of contact points makes the forces more balanced and distributed more effectively. On the contrary, it causes pain in the jaw joint or it can also affect the upper cervicals and these in turn, in the rest of the human body.

According to Martínez Medina I, and et. Col (2009) mention that Meersseman in her article establishes that $30-40 \%$ of back pain can be caused or aggravated by a dental malocclusion.

The jaw articulates with the skull through the temporomandibular joint. And the skull, in turn, articulates with the vertebral column (upper cervical).

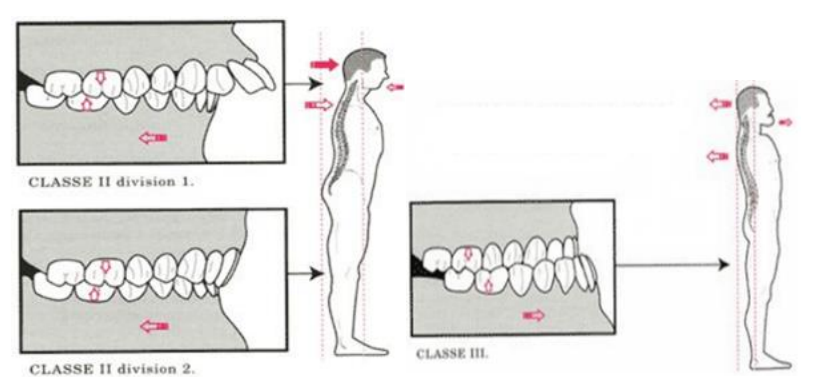

Figure 1 Relationship of malocclusion and body posture. 
Class I malocclusion is characterized by a normal anteroposterior relationship of the first permanent molars. Wherein the mesiobuccal cusp of the upper first molar is in the same plane as the buccal sulcus of the lower first molar. Malocclusions in this class consist of individual malpositions of the teeth, abnormal vertical or transverse relationships, or sagittal deviation of the incisors. Painted Gálvez 2017.

Class II malocclusion manifests when the first lower molars occlude distally in their normal relationship with the first upper molars with a length greater than half the width of a cusp on each side and with this successively the other teeth will occlude abnormally and be forced to a distal occlusive position, causing more or less retrusion or underdevelopment of the mandible. For this class there are two divisions, each with its subdivision. The great difference between these two divisions is manifested in the positions of the incisors, in the first being protruded and in the second being retruded. Painted Gálvez 2017.

Class III malocclusion Known as prognathism or submorida, it is produced by the mesial occlusion of the two hemiarcades of the lower dental arch with an extension of slightly more than one half the width of a cusp on each side. Moderate to severe crowding may occur in both arches, mainly in the upper arch. Lingual inclination of the lower incisors and canines is also observed, which becomes more pronounced the more severe the case, this is due to the pressure of the lower lip in its attempt to close the mouth and hide the malocclusion. The neuromuscular system is altered so there is a mandibular bone protrusion, maxillary retrusion or both. The facial profile can be divergent posterior and labial concave. Painted Galvez 2017.

\section{Goals}

\section{Overall objective}

Establish the types and frequency of body postures and dental malocclusions in patients from the Faculty of Dentistry in the AugustDecember 2019 period.

\section{Specific objectives}

Observe the most frequent posturological alterations.

- Identify the relationship between the type of malocclusion in the sample.

- $\quad$ Relate the frequency of the type of Angle Class with the body posture.

\section{Methodology to be developed}

Cross-sectional, descriptive and observational study. The sample consisted of a total of 50 patients between the ages of 19 and 70 who attended the Admission Clinic of the Faculty of Dentistry. To whom it was performed: verification of molar class, verification of midline deviation, verification of posterior crossbite, external lateral palpation of the TMJ, extraoral photographs, analysis of photographs.

\section{Results}

It was found that $48 \%$ of the population studied had some type of dental malocclusion. Of which $60 \%$ presented Angle Class I malocclusions; $12 \%$ Class II and 28\% Class III.

Regarding the occlusion, it was found that $58 \%$ had a midline deviation and $10 \%$ had a crossbite.

When the presence of back pain was related in relation to patients with malocclusions, it was found that $16 \%$ frequently present pain, $2 \%$ refer to always present it and $36 \%$ occasionally present back pain.

In relation to the type of body posture, the results were the following: $28 \%$ Ideal Posture; 30\% Flattened; 24\% Military; $10 \%$ Kypholordic and 8\% Arched back.

Regarding the Type of malocclusion according to the Angle Classification, the positions most found were:

Class I, Flattened Posture followed by the Ideal Posture.

Class II, Military Posture. 
Class III, Flat Posture followed by Ideal Posture.

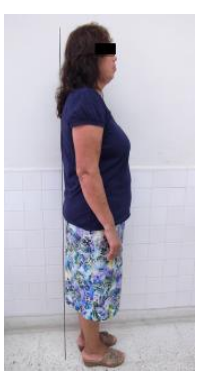

Flattened Posture

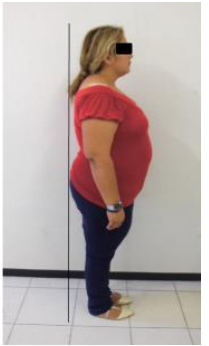

Cifolordic Posture

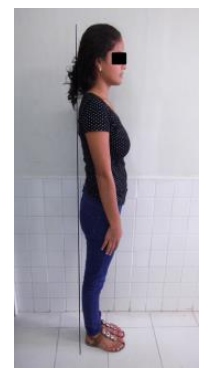

Ideal Posture

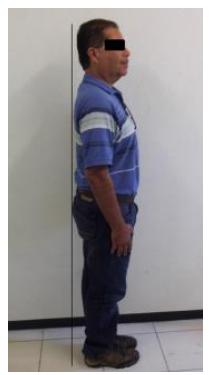

Military Posture
Figure 2 Found positions

\section{Discussion}

Murrieta (2013), an incorrect postural attitude is considered an etiological factor of malocclusions, since it instantly modifies the relationship between the two jaws.

Martinez Medina I, and et. Col 2009, Meersseman: pain due to dental malposition of $30-40 \%$ of back pain can be caused or aggravated by a dental malocclusion.

Machado et al., (2009), when there is a deviation of the dental midline and there is a displacement of the jaw, scoliosis can occur.

\section{Conclusions}

There is a high frequency of a type of body posture and Class I Angle malocclusions in patients treated in this study.

The female gender predominated. In relation to malocclusions, Angle's Class I predominated, as well as in these patients the flattened posture. in Class II the military one and in Class III both the flattened and the ideal.

\section{Recommendations}

Conduct studies with a larger sample that allows us to accurately determine postural alterations and their relationship with the different types of malocclusions.
Include the occlusal-postural correlation in the occlusion course and in the diagnostic review, in such a way that this allows the dentist to be able to guide patients in relation to the importance of attending a dental malocclusion not only due to aesthetic, masticatory and phonetics, but because of the importance it can have on your body posture and therefore on your general health and wellbeing.

\section{References}

González Espangler, L., Durán Vázquez, W. E., Ramírez Quevedo, Y., Leyet Martínez, M. R., \& Cabrera Sánchez, T. V. (2016). Relación de la postura corporal con las maloclusiones en adolescentes de un área de salud. MEDISAN, 20(12), 6001-6008.

Inquilla Apaza, Gisenia Pilar, Padilla Cáceres, Tania Carola, Macedo Valdivia, Sonia Caroll, \& Olaguivel, Nedy Hilari. (2017). Relación de la Maloclusión dentaria con postura corporal y huella plantar en un grupo de adolescentes aymaras. Revista de Investigaciones Altoandinas, 19(3), 255264. https://dx.doi.org/10.18271/ria.2017.290

José Francisco Murrieta Pruneda. Dental malocclusion and its relationship with body posture: a new research challenge in Stomatology. Bol Med Hosp Infant Mex 2013;70(5):341-343.

Machado H, Quiros O, Maza P, Fuenmayor D, Jurisic A, Alcedo C, Ortiz M. Correlación de la huella plantar y las maloclusiones en niños de 5 a 10 años que asisten a la escuela Arturo Uslar Pietri en Maturín, EDO. Monagas. Rev LatinoAm de Ortodoncia y Odontopediatría 2009;11:1-22.

Mariel, J., Flores, J., Gutiérrez, F., Mariel, G, Sánchez, W., y Guerrero, A. (2015) Estudio morfométrico de la posición cráneo-cervical en pacientes con clases esqueletales II y III. Int. J. Morphol., 33(2), 415-419.

Martinez Medina I., Bleró, Navarro Montes C., Ratia Martinez F., Sánchez Aguilera F. El dolor de espalda causado por malposiciones dentarias (Quinesiología dental, posturología y Odontología del deporte). Gaceta Dental, Abril 2009, Granada, España. 
Parrilla, J. M. M., da Conceição Morais Chipombela, L., \& Semykina, O. (2014). La oclusión dentaria en interacción con la postura corporal. Revista

Cubana

Estomatologia, 51(1), 15-23.

Patiño Mayer, B., Montenegro, A., Pison, J. I., Fanucchi, A., Bianco, A., \& Garrido, Y. (2017). Evaluación de la postura corporal en estudiantes ingresantes al nivel universitario. Revista Argentina de Anatomia Online, 8(4), 225.

Pintado Galvez, Jazmin Nathaly (2017). Relación de maloclusiones dentales (Clasificación de Angle) y postura corporal en escolares de 9 a 11 años de la Unidad Educativa J. M. Jijón Caamaño y Flores de AmaguañaQuito, en el año 2017. Proyecto de investigación presentado como requisito previo a la obtención del título de Odontóloga. Carrera de Odontología. Quito : UCE. p. 65. 